\title{
Efeitos do Comprimento de Reversão e do Ângulo de Ataque sobre a Estrutura de Solidificação do Cordão em Soldagem MIG/MAG com "Switch Back"
}

\author{
(Effects of the Reversion Course Length and Torch Leading Angle on the Bead Solidification Structure in GMAW Welding \\ with Switch Back)
}

\author{
Hélio Antônio Lameira de Almeida ${ }^{1}$, Carlos Alberto M. da Mota ${ }^{2}$, Américo Scotti $^{3}$ \\ ${ }^{1}$ Instituto Federal de Educação, Ciência e Tecnologia do Pará, Mecânica, Belém, PA, Brasil, almeidahelio@yahoo.com.br \\ ${ }^{2}$ Universidade Federal do Pará, Faculdade de Engenharia Mecânica, Belém, PA, Brasil \\ ${ }^{3}$ Universidade Federal de Uberlândia, Faculdade de Engenharia Mecânica, Uberlândia, MG, Brasil
}

\begin{abstract}
Resumo
A técnica "Switch Back" consiste em oscilar a toch a durante a soldagem na direção do cordão e não transversalmente. Entretanto, pouco se conhece a respeito dos aspectos metalúrgicos do metal de solda depositado por essa técnica. Assim, neste trabalho é apresentado um estudo qualitativo do efeito do ângulo de ataque da tocha e do comprimento de reversão sobre a estrutura de solidificação do cordão. As soldagens foram realizadas com o processo MIG/MAG Pulsado sobre chapas de aço com baixo teor de carbono. Os resultados mostraram que os parâmetros analisados modificam a forma de como a solidificação do cordão se realiza. No geral, quando o ângulo da tocha exerce o movimento empurrando-puxando, favorece-se a formação de grãos equiaxiais próximo à linha de fusão. Quanto ao comprimento de reversão, o seu aumento propicia o refino destes grãos.
\end{abstract}

Palavras-chaves: Switch back; Estrutura de Solidificação, $M I G / M A G$

Abstract: The welding technique denominated switch-back technique consists in a torch oscillation in the welding direction rather than transversally. However, there is not much information in literature about the solidification structure of the bead when this technique is applied. Therefore, in this work is presented a study on the effect of the torch leading angle and of the reversion course length over the bead solidification structure. Welds were carried out with Pulsed MIG/MAG Process on plain carbon steel plates. The results showed that the parameters under analysis modify the solidification mode of the bead. In general, when the angle of torch leads to pushing-pulling movement, equiaxial grains near the fusion line is favored. In relation to the course length, its increase leads to finer solidification structure.

Key-words: Switch back; Bead Solidification Structure, GMAW

\section{Introdução}

Pela técnica "Switch-back", a tocha do processo MIG/ MAG é conduzida por um robô a oscilar na direção longitudinal do cordão. Ela realiza várias reversões no sentido contrário ao da soldagem, como apresentado na Figura 1. Inicialmente, a tocha é deslocada para frente (avanço) em um determinado comprimento e, em seguida, deslocada para trás (reversão) em um comprimento cerca da metade do anterior. Estes dois movimentos da tocha se repetem durante a soldagem e podem ser realizados com velocidades iguais ou diferentes.

Pesquisas desenvolvidas recentemente com esta técnica no LAPROSOLDA (Centro para Pesquisa e Desenvolvimentos de Processos de Soldagem da Universidade Federal de Uberlândia) permitiram mostrar que ela pode promover o aumento da

(Recebido em 29/02/2012; Texto final em 03/03/2012).

Artigo originalmente publicado no CONSOLDA 2011 velocidade limite de soldagem. Aplicada ao processo MIG/ MAG Pulsado no modo automático (tocha adaptada em robô), permitiu um aumento da velocidade de soldagem em até $60 \%$, quando usado juntas sobrepostas com chapas de aço de 3 $\mathrm{mm}$ de espessura, aumentando ainda mais a produtividade do processo; sem a utilização da técnica, a velocidade de soldagem máxima alcançada para a realização dos cordões com aparência e penetração adequados foi de $35 \mathrm{~cm} / \mathrm{min}$, enquanto que com a técnica a velocidade de soldagem máxima alcançada foi de 57 $\mathrm{cm} / \mathrm{mim}[1]$.

Outros trabalhos [2, 3, 4] investigaram o potencial desta técnica no controle da raiz da solda na soldagem MIG/MAG em corrente pulsada de juntas de topo sem a utilização de cobrejunta. Kaneko et al [2], na união de chapas de aço de 3,2 mm de espessura posicionadas em topo, verificaram que o uso da técnica permitiu o controle da raiz da solda em relação a soldagem MIG convencional. Este controle cresceu quando utilizou-se maior nível de velocidade de soldagem durante o avanço da tocha em relação a reversão. Yamane et al $[3,4]$ utilizaram com sucesso a combinação da técnica Switch-back com o tecimento transversal ao cordão de solda na soldagem MIG Pulsado de juntas de topo 


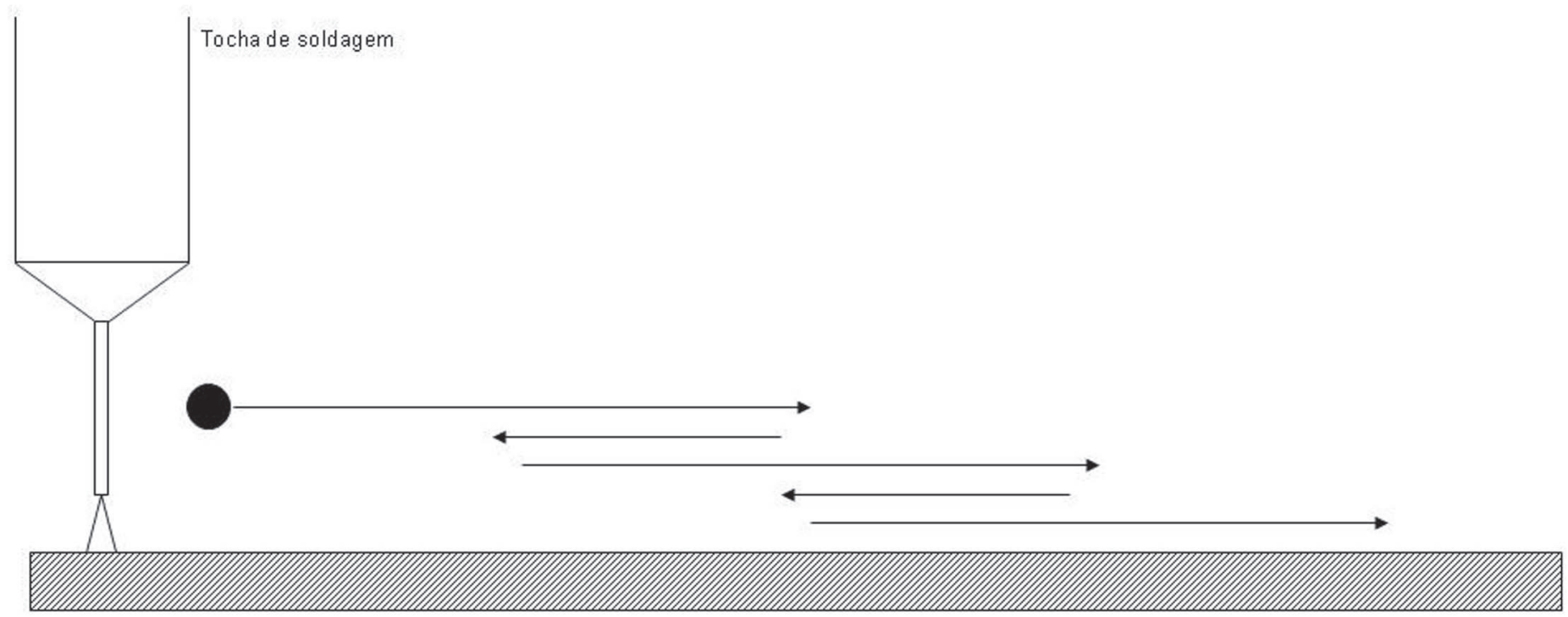

Figura 1 - Ilustração da técnica "Switch-back"

com chanfro em V, em chapas de espessura média, sem cobrejunta e abertura grande de raiz. No tocante a parte do switchback, a idéia foi fazer o passe de avanço sobre a parede da junta e o retrocesso sobre o centro. Deve ser ressaltado que quando a tocha aproxima-se das bordas da raiz da junta, a corrente pulsada atinge o seu valor de pico transferindo a gota metálica, e, quando aproxima-se do centro da junta, a corrente atinge o seu valor de base, não ocorrendo transferência de metal, controlando assim a raiz da solda. Desta maneira, foi possível a confecção de soldas com boa aparência e, principalmente, sem a perfuração da raiz da junta. Yamane et al verificaram ainda a aplicação de um sistema de controle automático da alimentação do arame e da velocidade dos movimentos da tocha (avanço e recuo) na soldagem MIG pulsada de juntas de topo com chanfro em V. Com este sistema de controle, as velocidades de alimentação do arame e de soldagem da tocha são ajustadas em tempo real durante a soldagem no caso de haver variações na abertura de raiz devido ao calor do arco elétrico, permitindo a confecção de soldas com raiz aceitável.

Apesar de algumas evidências das vantagens da técnica switch-back para soldagem MIG/MAG, pouco se sabe a respeito das características metalúrgicas dos cordões produzidos com a técnica. Sabe-se da literatura [5] que quando um passe de solda é realizado sobre o anterior (soldagem multi-passes), o passe anterior é tratado termicamente e pode apresentar melhoras nas propriedades mecânicas do material soldado, como a sua tenacidade. No caso da Técnica Switch-back, um passe acaba sendo realizado sobre parte do anterior. Porém há uma grande diferença. Durante a reversão o passe anterior pode estar ainda totalmente líquido, em processo de solidificação ou já solidificado, porém ainda quente. Tudo isto dependendo dos parâmetros de avanço e reversão (curso e velocidade, para uma dada corrente). Assim, a proposta deste trabalho é investigar o efeito desta refusão sobre as características metalúrgicas dos cordões produzidos, para diferentes condições operacionais da técnica.

\section{Materiais e Métodos}

Todas as soldagens foram realizadas por um equipamento comercial para MIG pulsado sinérgico na posição plana e de forma automática (robotizada), sobre placas de teste $(180 \mathrm{~mm} \times 50 \mathrm{~mm}$ x 4,7 mm) de aço com baixo teor de carbono. A proteção do arco elétrico foi realizada pela mistura gasosa $95 \% \mathrm{Ar}+5 \% \mathrm{O}_{2}$, a uma vazão de $15 \mathrm{l} / \mathrm{min}$. O arame-eletrodo utilizado foi o ER70S-6 com 1,2 mm de diâmetro e o comprimento livre do eletrodo foi de $18 \mathrm{~mm}$. A Tabela 1 apresenta as condições operacionais para a corrente pulsada utilizada neste trabalho, enquanto a bancada de soldagem utilizada durante os experimentos está apresentada na Figura 2.

Tabela 1 - Parametrização do processo MIG/MAG para corrente pulsada

\begin{tabular}{|c|c|c|c|c|c|}
\hline $\begin{array}{c}\text { Valim } \\
(\mathrm{m} / \mathrm{min})\end{array}$ & $\begin{array}{c}\mathrm{Im} \\
(\mathrm{A})\end{array}$ & $\begin{array}{c}\mathrm{Ip} \\
(\mathrm{A})\end{array}$ & $\begin{array}{c}\mathrm{Ib} \\
(\mathrm{A})\end{array}$ & $\begin{array}{c}\mathrm{tp} \\
(\mathrm{ms})\end{array}$ & $\begin{array}{c}\mathrm{tb} \\
(\mathrm{ms})\end{array}$ \\
\hline 4,0 & 145 & 510 & 75 & 1,7 & 9,4 \\
\hline
\end{tabular}

Na soldagem com a técnica Switch Back, o posicionamento da tocha, puxando ou empurrando, é modificado de acordo com o movimento. Se a tocha avançar com a inclinação puxando, a reversão é realizada de forma empurrando (condição denominada aqui de "puxando-empurrando"). Similarmente, se a tocha avançar com a inclinação empurrando, ela recua puxando (condição "empurrando-puxando"). Utilizou-se uma inclinação para a tocha de $\pm 15^{\circ}$. Durante todos os experimentos, foi mantida constante a velocidade equivalente de soldagem em $25 \mathrm{~cm} / \mathrm{min}$. Velocidade equivalente é definida como aquela com a qual pode ser produzido um determinado comprimento de solda pela técnica switch-back em um mesmo tempo em que se gasta para fazer um outro cordão, com o mesmo comprimento, sem o emprego da técnica.

A avaliação do efeito da reversão e da inclinação da tocha 


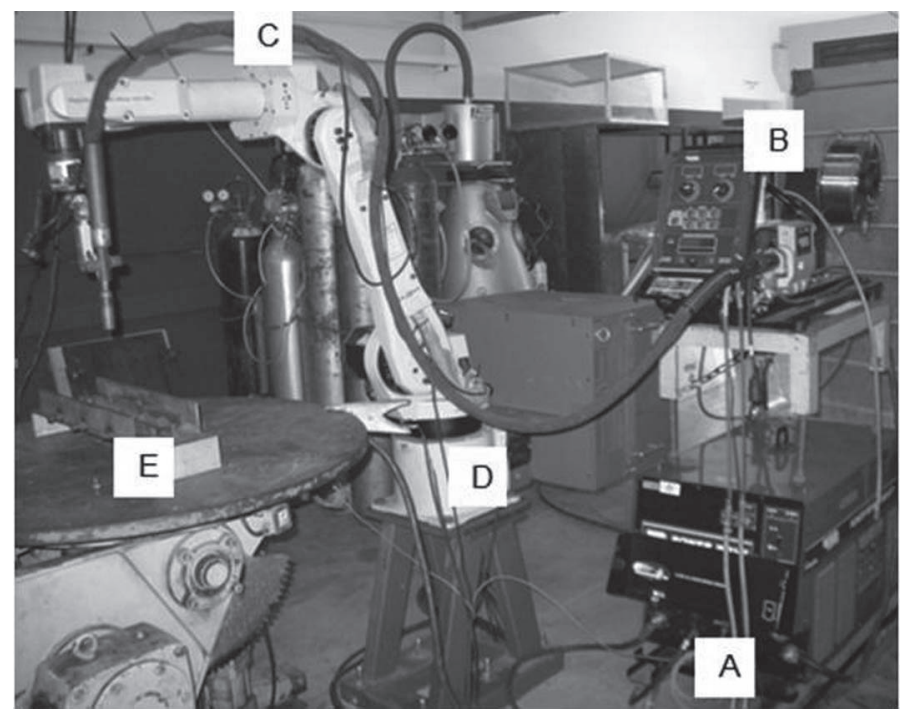

Figura 2 - Bancada de soldagem: (A) Fonte de soldagem; (B) Cabeçote alimentador de arame; (C) Tocha de soldagem;

(D) Robô; (E) Suporte de fixação das placas de teste

na soldagem switch-back sobre a estrutura de solidificação do cordão foi realizada em duas etapas. Na primeira, as soldagens foram realizadas em uma única reversão, a qual teve o mesmo comprimento do cordão (140 mm, padrão para toda as soldas), como indicado na Figura 3. A velocidade empregada na tocha foi de $50 \mathrm{~cm} / \mathrm{min}$ para manter constante a velocidade equivalente de soldagem. Foi importante produzir soldas nesta condição para que fosse observado o efeito de uma única reversão. Foram soldadas duas placas de teste, um na condição puxandoempurrando e outro na empurrando-puxando (as duas soldagens foram replicadas).

(a)

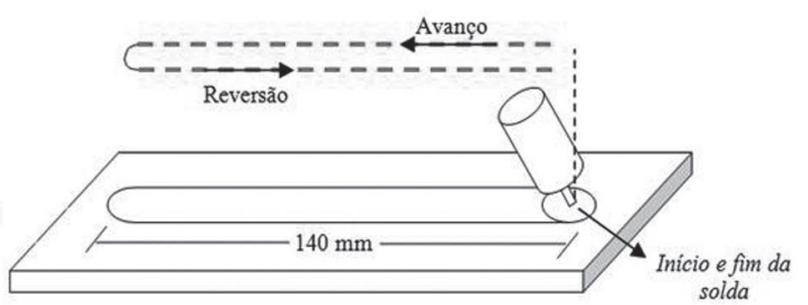

(b)

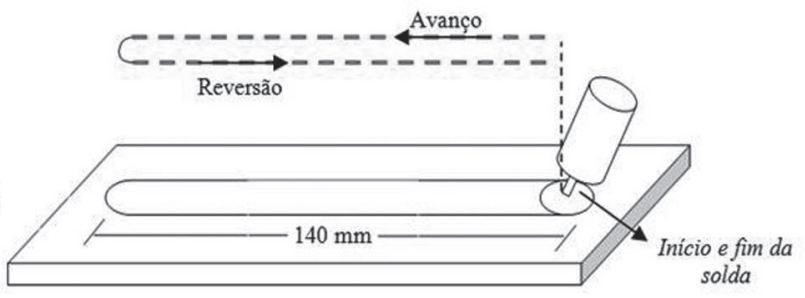

Figura 3 - Ilustração da soldagem MIG Pulsado Switchback com reversão única: (a) condição puxando-empurrando; e

(b) condição empurrando-puxando

$\mathrm{Na}$ segunda etapa, foram realizadas soldagens com múltiplas reversões de comprimentos limitados, até atingir um comprimento total de cordão de $140 \mathrm{~mm}$. Os comprimentos da reversão estudados foram de $5 \mathrm{~mm}, 15 \mathrm{~mm}, 20 \mathrm{~mm}$ e $50 \mathrm{~mm}$. Uma placa de teste foi também soldada sem reversão para efeito de comparação. As condições operacionais estudadas da técnica switch-back durante esta etapa são apresentadas na Tabela 2.

Tabela 2 - Condições operacionais da técnica Switch-back avaliadas com velocidades equivalentes de $25 \mathrm{~cm} / \mathrm{min}$

\begin{tabular}{|c|c|c|c|}
\hline \multicolumn{2}{|c|}{ Comprimento } & \multicolumn{2}{c|}{ Velocidade da tocha } \\
\hline $\begin{array}{c}\text { Avanço } \\
{[\mathrm{mm}]}\end{array}$ & $\begin{array}{c}\text { Reversão } \\
{[\mathrm{mm}]}\end{array}$ & $\begin{array}{c}\text { Avanço } \\
{[\mathrm{cm} / \mathrm{min}]}\end{array}$ & $\begin{array}{c}\text { Reversão } \\
{[\mathrm{cm} / \mathrm{min}]}\end{array}$ \\
\hline 10 & 5 & 74 & 74 \\
\hline 30 & 15 & 46 & 46 \\
\hline 30 & 20 & 111 & 111 \\
\hline 60 & 50 & 200 & 200 \\
\hline
\end{tabular}

Para avaliação das microestruturas após soldagem, seções transversais e longitudinais das placas de teste (Figura 4) foram retiradas e embutidas a frio com resina epóxi. Em seguida, as suas superfícies foram submetidas ao processo de lixamento $(180,220,320,400,600,1200$ e 2000 Mesh) e polimento com alumina de granulométrica de 1 mícron. Finalmente, elas foram atacadas com Nital $2 \%$ por imersão durante um tempo de 1 min.

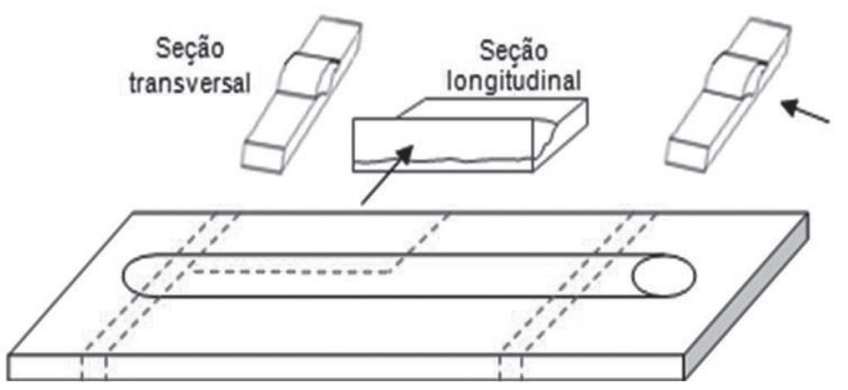

Figura 4 - Ilustração das regiões onde foram retiradas as amostras para análise metalográfica

\section{Resultados e Discussão}

\subsection{Soldagens com uma única reversão - etapa 1}

\subsubsection{Efeito da reversão}

Para estudar o efeito da reversão, foi usada a placa de teste produzida na condição puxando-empurrando. A Figura 5 apresenta as macrografias obtidas de seções transversais da solda. Por esta figura, verifica-se que na seção A-A (início da reversão) a estrutura de solidificação apresenta-se no estado bruto de fusão, com grãos fortemente colunares. Já na seção B-B (um tempo maior entre o passe de avanço e o de reversão), verifica-se a geometria do passe de avanço fica remanescente (indicando que a penetração se deu no passo de avanço), mas percebe-se a recristalização dos grãos colunares na região do fundo do cordão, tal como ocorre em soldagens multipasses. Também se percebe que o cordão ficou menos convexo na seção 

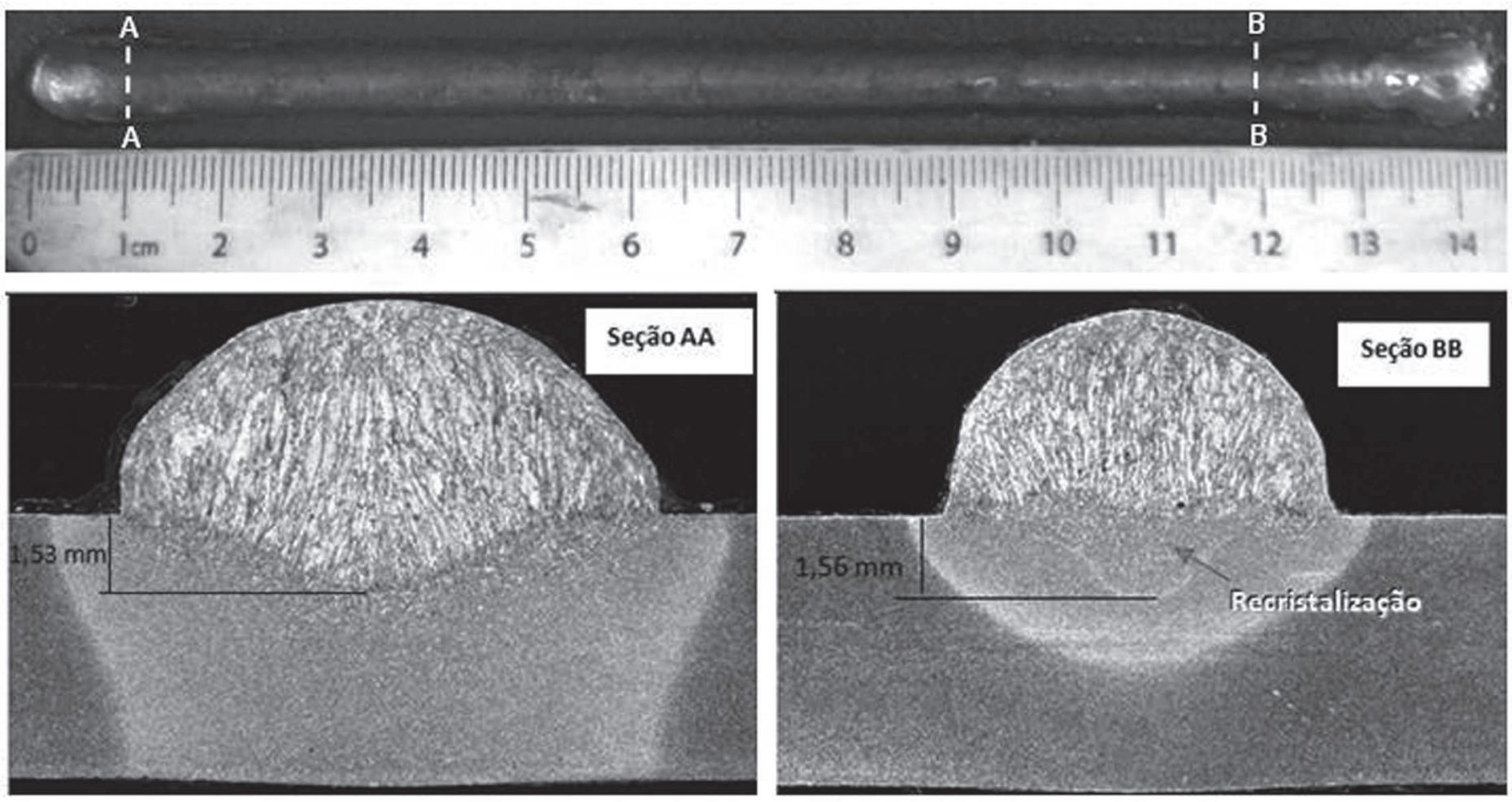

Figura 5 - Seções transversais em diferentes posições da soldagem puxando-empurrando com $140 \mathrm{~mm}$ de avanço e $140 \mathrm{~mm}$ de reversão: a seção AA está à aproximadamente $10 \mathrm{~mm}$ do ponto de reversão, enquanto a seção B-B está a $120 \mathrm{~mm}$

A-A, mas com uma distribuição de calor que favorece uma maior ZTA (inclusive com grãos mais grosseiros, $Z T A-G G$ ). A ZTA grosseira do segundo passe na seção B-B estaria sobre a região anteriormente colunar do primeiro passe, enquanto a região de normalização do segundo passe (ZTA com grãos finos, ZTA$G F)$ estaria sobre a região grosseira da ZTA do primeiro passe, como detalha-se melhor na Figura 6. Pode-se, assim, prever que melhores propriedades seriam conseguidas com distância de retrocesso maiores, mas deve-se lembrar que em uma soldagem switch-back haveria um novo passe de avanço sobre uma seção do tipo B-B.

Estas características diferenciadas sugerem que na seção A-A a poça ainda estava líquida durante a reversão, ao contrário da seção B-B. Assim, em A-A o calor imposto seria 2 vezes o calor individual das soldagens em cada direção, ou seja, como se a tocha tivesse viajado em menor velocidade. Já em B-B, percebe nitidamente um passe sobre outro passe. A energia de soldagem de cada desses passes é a de cada passe individualmente. Isto justifica a recristalização e a menor ZTA nessa seção, que, como mencionado, deve ter melhores propriedades mecânicas e possivelmente menos tensões térmicas residuais (mas a análise sobre este aspecto é mais complexa e não será foco deste trabalho). A Figura 5 evidencia, ainda, que a região do cordão na qual foi extraída a seção A-A apresentou um maior volume de metal depositado. Isto pode estar relacionado com a inércia do robô durante a reversão, ou seja, a tocha permaneceu um tempo maior neste trecho, até alcançar a velocidade empregada, e, com isso, foi depositada uma maior quantidade de material.

Para melhor avaliar o início desta recristalização com a reversão da tocha, foi reproduzida uma réplica em outra placa de teste. Neste caso, foi analisada a seção longitudinal do cordão produzido. A Figura 7 apresenta a macroestrutura do metal de solda obtida nesta seção. Nesta figura, é possível observar três regiões com diferentes morfologias de solidificação. Na região 1, formada antes de cerca de $10 \mathrm{~mm}$ do ponto de reversão, a morfologia mais para o centro do cordão é de grãos colunares, que perde um pouco esta característica devido ao aparecimento de grãos equiaxiais próximos a linha de fusão. Isto indica que mesmo logo após a reversão (aproximadamente 1,2 s depois), o comportamento não é $100 \%$ como se fosse uma poça única (fenômeno inesperado).

$\mathrm{Na}$ segunda região, iniciada a $10 \mathrm{~mm}$ da reversão (a cerca de $1,2 \mathrm{~s}$ ), a macroestrutura se apresenta com grãos colunares próximo a linha de fusão e se estende para a região central (esta estrutura de solidificação se manteve ao longo de grande comprimento da solda avaliado), indicando o comportamento ser de uma poça única. A justificativa para esta diferença entre as regiões 1 e 2 pode ser explicada da seguinte forma: na região 1 , devido à reversão, é possível se ter maiores perdas de calor para a frente do cordão, ou seja, está ainda em regime transitório, ao contrário da região 2 . A região 2, que foi também ilustrada pela seção A-A na Figura 5, se caracteriza por ser longa (aproximadamente de $25 \mathrm{~mm}$ para a dada energia imposta).

Porém, a partir de $32 \mathrm{~mm}$ do ponto de reversão, ou 3,84 s da reversão, marcada como início da região 3 , foi possível notar, pela seção longitudinal, uma mudança de formação macroestrutural. A estrutura de solidificação do metal de solda é caracterizada por grãos colunares mais no centro do cordão, 


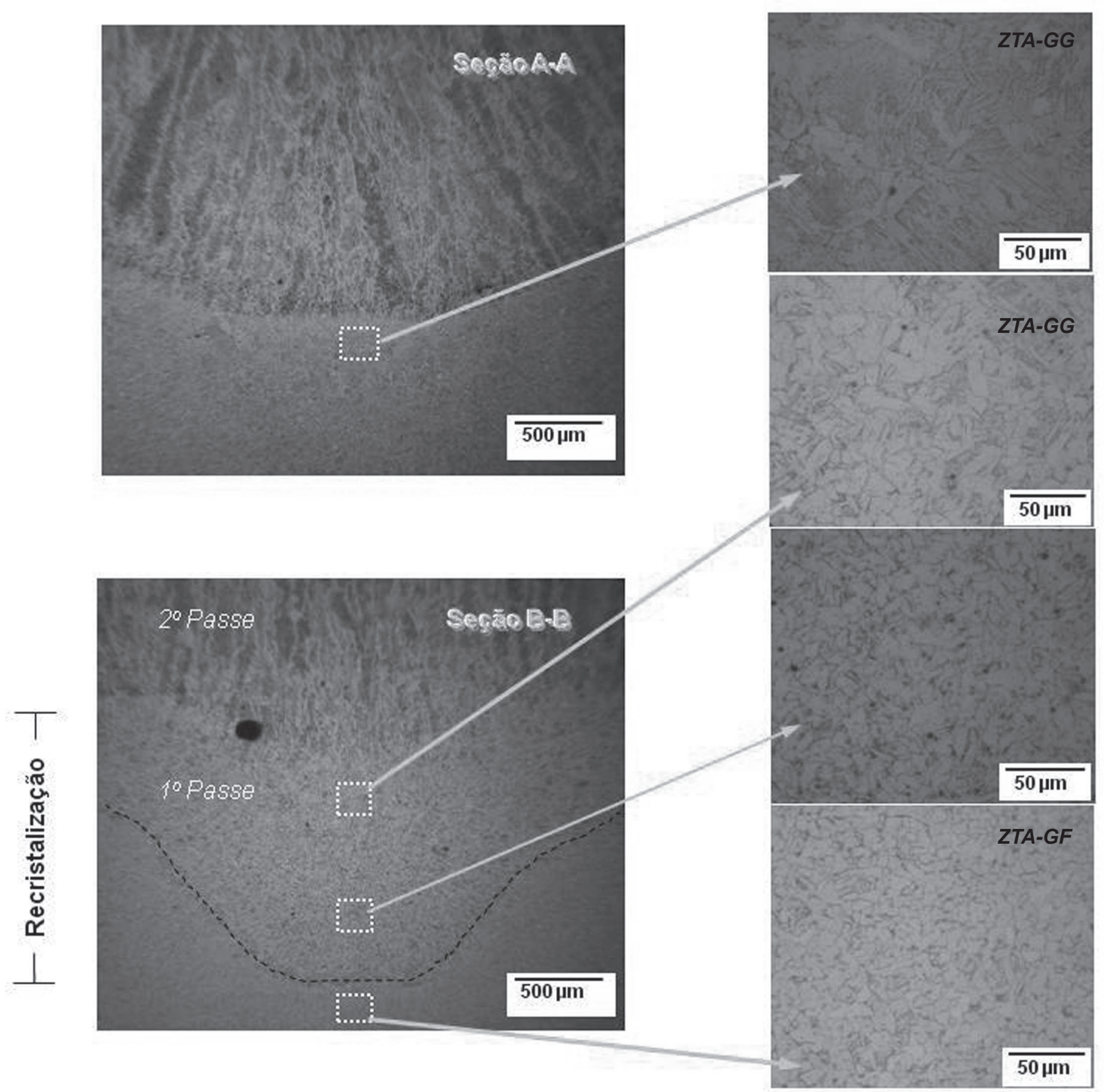

Figura 6 - Detalhamento das ZTAs das seções A-A e B-B indicadas na figura 5

passando para grãos recristalizados próximo à linha de fusão. Nota-se ainda na região da ZTA grosseira original um refino total dos grãos (normalização). A região 3 se equivalem à seção B-B da Figura 5.

Desta forma, pode-se prever durante a reversão 3 regiões, a primeira próximo da reversão (que poderia ser chamada de região semi-recristalizada), a segunda um pouco afastada (que poderia ser chamada de região sem recristalização) e a terceira mais afastada (que poderia ser chamada de região com recristalização). Naturalmente, o comprimento e a distância entre essas regiões dependem principalmente para um dado modo operacional do processo, da corrente, velocidade de soldagem e inclinação da tocha.

\subsubsection{Efeito da inclinação da tocha}

Para avaliar o efeito da inclinação da tocha durante a reversão, usou-se a soldagem produzida na condição empurrando-puxando, para comparar com o resultado da soldagem na condição puxando-empurrando (item 3.1.1). A 


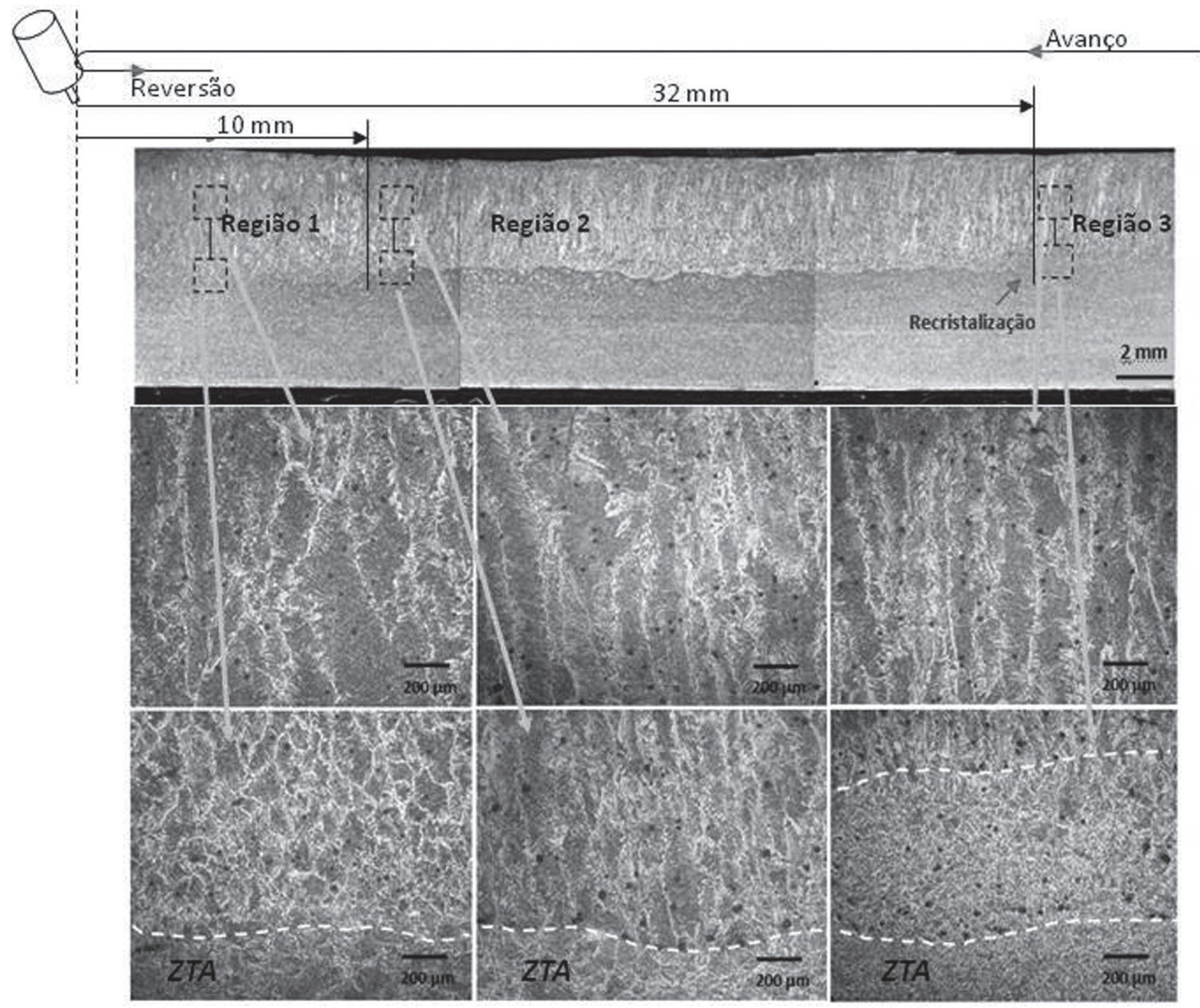

Figura 7 - Seção longitudinal de uma soldagem na condição puxando-empurrando, com $140 \mathrm{~mm}$ de avanço e 140 mm de reversão: ampliações das seções de cada região são apresentadas pelas figuras na parte inferior

Figura 8 apresenta as macrografias obtidas da seção transversal de uma solda produzida nessa condição. Verifica-se nesta figura que também ocorreu a rescristalização de grãos do metal de solda no fim da reversão (seção B-B), porém em uma menor área do que aquela observada na Figura 5. Também foi menor a ZTA e a penetração, fatos não observados em relaçào a seção A-A.

Já a Figura 9 apresenta macroestruturas de regiões de uma seção longitudinal tirada no centro do cordão réplica da soldagem apresentada na Figura 8. Resultado similar àquele apresentado na Figura 7 foi encontrado para a estrutura de solidificação do metal de solda produzido na condição empurrando-puxando. Também foram observadas as três diferentes regiões com estrutura de solidificação, ou seja, a região semi-recristalizada, a região sem recristalização e a região com recristalização, porém menos caracterizadas (dificultando mensurar o início das mudanças macroestruturais).

$O$ fato da recristalização ter sido mais evidente na condição puxando-empurrando deve estar relacionado com o comportamento da penetração alcançada pela poça de fusão durante a soldagem. Nessa última condição, o avanço da tocha foi realizado na condição puxando, porém, quando a tocha passou para o movimento de recuo, a condição de soldagem mudou automaticamente para empurrando, uma vez que não foi alterada a angulação da tocha neste instante. Como é conhecido na literatura [6], a soldagem puxando apresenta uma penetração maior da poça de fusão do que a soldagem empurrando. Assim, quando a tocha avançou, a penetração da solda foi maior do que quando recuou e este passe de recuo, com menor penetração, não refundiu completamente o passe anterior, deixando uma maior área favorável para recristalizar os grãos. A ilustração proposta na Figura 10 ajuda a compreender esta explicação. Então, os resultados encontrados na etapa 1 apontam que a inclinação da tocha mais indicada para a soldagem switch-back seria aquela em puxando-empurrando, pois permitiu uma maior área para a recristalização de grão do metal de solda. 

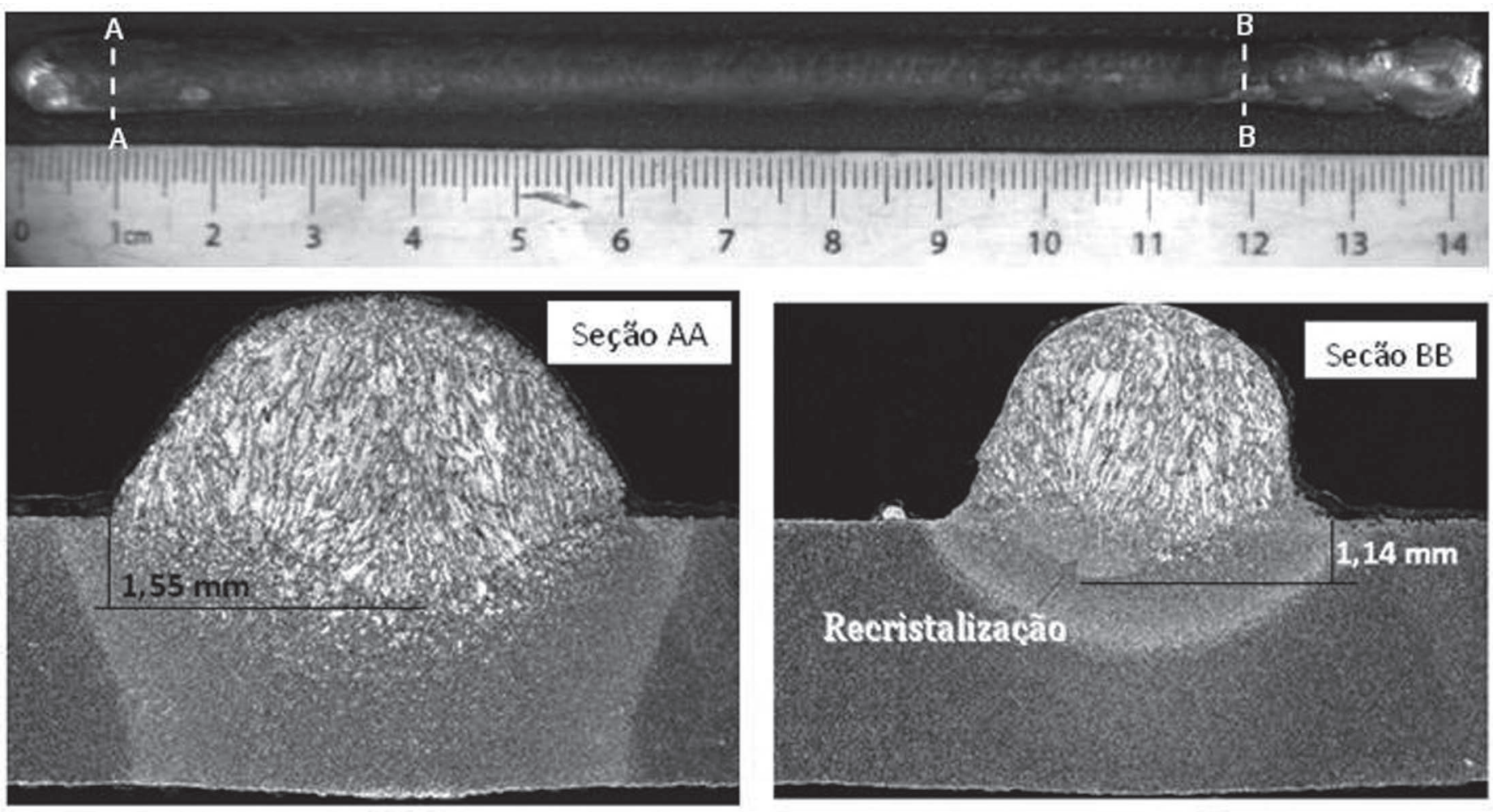

Figura 8 - Seções transversais em diferentes posições da soldagem empurrando-puxando com 140 mm de avanço e 140 mm de reversão: a seção AA está à aproximadamente $10 \mathrm{~mm}$ do ponto de reversão, enquanto a seção B-B está a $120 \mathrm{~mm}$

\subsection{Soldagens com múltiplas reversões - etapa 2}

\subsubsection{Efeito da variação do comprimento da reversão}

Pelos resultados obtidos anteriormente, todas as soldagens deveriam ser produzidas na condição puxando-empurando. Entretanto, na soldagem com múltiplas reversões, o recuo da tocha é seguido de um avanço. Assim, as soldagens nesta etapa foram realizadas com a inclinação da tocha na condição empurrando-puxando. Os aspectos dos cordões produzidos estão ilustrados na Tabela 3. Nota-se que as soldas realizadas com reversões de $5 \mathrm{~mm}$ e $20 \mathrm{~mm}$ apresentaram uma geometria mais uniforme. Desta forma, somente esses cordões foram escolhidos para análise.

As estruturas de solidificação dos cordões com reversões de $5 \mathrm{~mm}$ e $20 \mathrm{~mm}$ são apresentadas nas Figuras 11 e 12, respectivamente. Olhando estas figuras, percebe-se, nitidamente, a presença de grãos equiaxiais próximos à linha de fusão, similar àquela estrutura obtida para a região 1 da Figura 7. Estes grãos parecem mais finos quando a reversão foi de 20 $\mathrm{mm}$. Ainda com relacão a este cordão, observa-se na Figura 12 a mudança na orientação dos grãos do metal de solda com as reversões. Essa mudança fica fácil de ser visualizada a partir das linhas tracejadas. Isto pode ter ocorrido ainda durante a fase de solidificação do cordão, em funcão da alteração de direção da frente de solidificação. A mudança na orientacão dos grãos também foi verificada no metal de solda produzido com $5 \mathrm{~mm}$ de reversão, porém de forma menos clara.

Não foi possível notar a presença de grãos recristalizados semelhantes àqueles encontrados na região 3 da Figura 7. Já a solda produzida sem o emprego da técnica apresentou uma estrutura de solidificação completamente colunar, como pode ser observado na Figura 13. Isto mostra que a técnica switch-back pode, de alguma forma, modificar a estrutura de solidificação do cordão próximo à linha de fusão.

Tabela 3 - Aspecto dos cordões produzidos com diferentes comprimentos de reversão

\begin{tabular}{|c|c|c|}
\hline Aspecto superficial & $\begin{array}{c}\text { Avanço } \\
\text { (mm) }\end{array}$ & $\begin{array}{l}\text { Reversão } \\
\text { (mm) }\end{array}$ \\
\hline 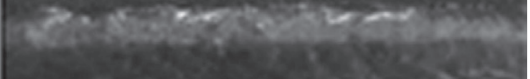 & 10 & 5 \\
\hline 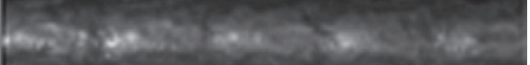 & 30 & 15 \\
\hline 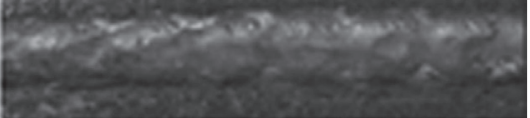 & 30 & 20 \\
\hline 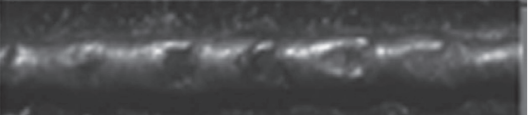 & 60 & 50 \\
\hline
\end{tabular}




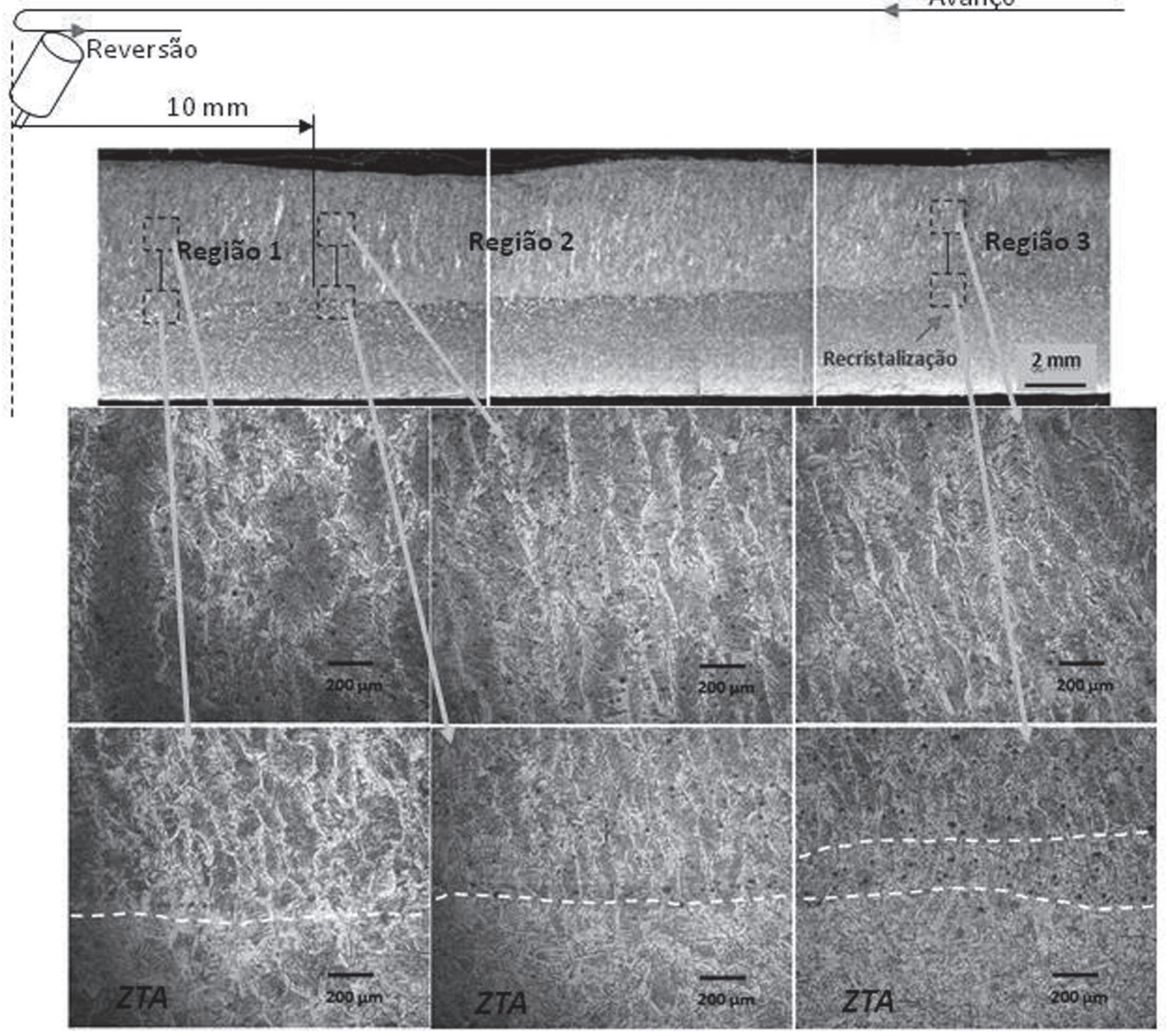

Figura 9 - Seção longitudinal de uma soldagem na condição empurrando-puxando, com 140 mm de avanço e 140 mm de reversão: ampliações das seções de cada região são apresentadas pelas figuras na parte inferior 
(a)
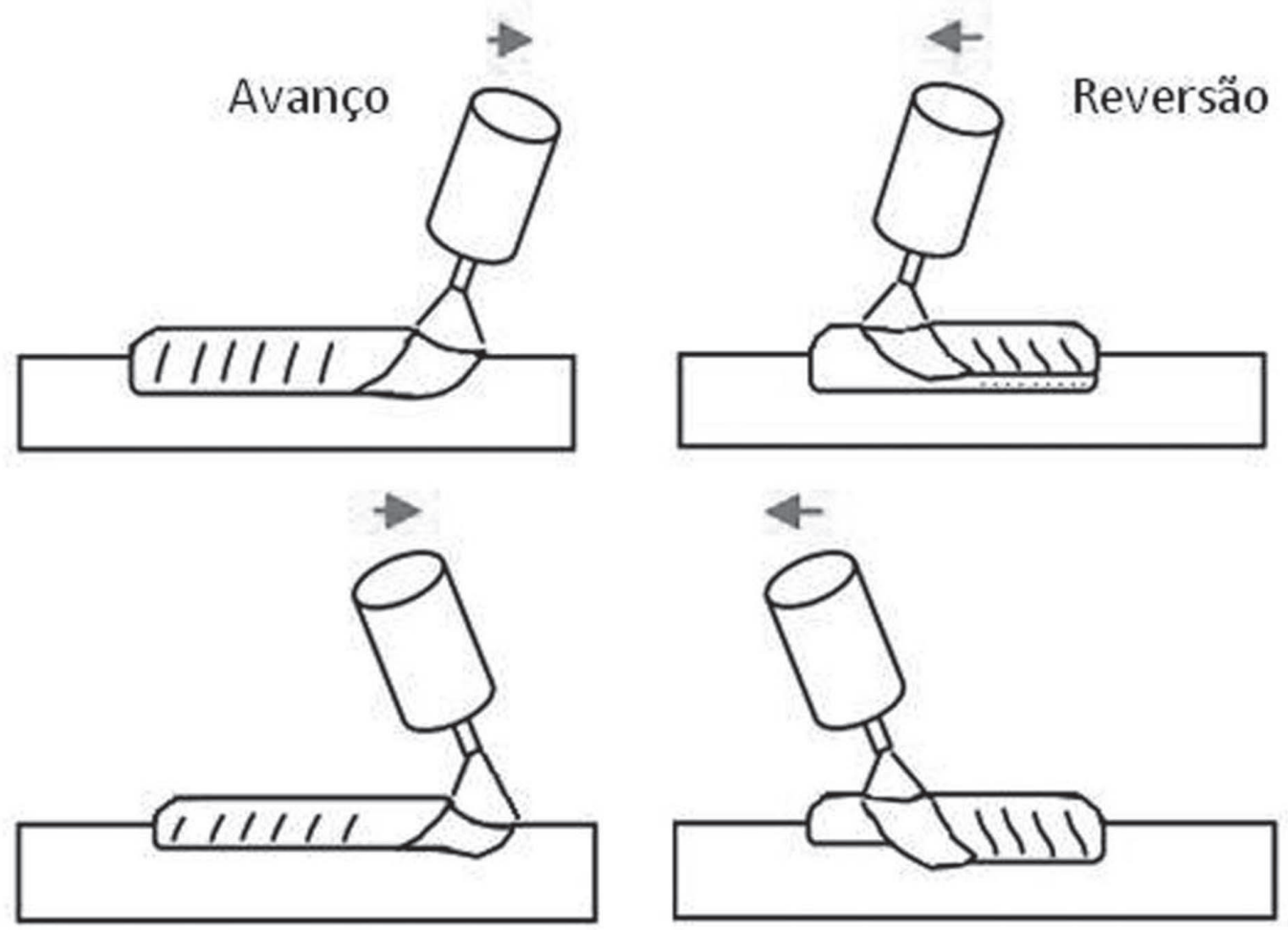

Figura 10 - Ilustração do efeito do ângulo da tocha sobre a estrutura de solidificação na soldagem Switch back: (a) Puxandoempurrando; (b) Empurrando-puxando

Em função dos pequenos comprimentos de reversão (5 $\mathrm{mm}$ e $20 \mathrm{~mm}$ ), passou-se a questionar se a formação dos grãos equiaxiais teria ocorrido durante a solidificação do metal líquido e não devido à algum tratamento térmico. Isto porque, talvez, não tivesse ocorrido tempo suficiente para a poça de fusão solidificar antes de ocorrer a reversão. Alguns mecanismos [5] explicam a formação destes grãos durante a solidificação do cordão. Dentre eles, podemos citar; o destacamento de grãos da zona parcialmente fundida que são levados para a poça líquida, fragmentação dendrítica da frente de solidificação, nucleação heterogênea e superresfriamento constitucional. Entretanto, estes mecanismos não explicam a formação de grãos equiaxiais próximo à linha de fusão, como o observado. Geralmente, verifica-se a formação desta estrutura equiaxial no centro do cordão. Então, como a estrutura equiaxial foi verificada apenas próximo à linha de fusão, volta-se a acreditar na idéia de estar ocorrendo algum tratamento térmico. Desta forma, pode ser que antes de ocorrer o avanço da tocha, apenas o fundo do cordão já havia solidificado e foi tratado termicamente logo em seguida, como o indicado na figura 14. Novamente, assim como ilustrado na figura 10, a inclinação da tocha pode estar favorecendo para a solidificação no fundo do cordão. Como o avanço é realizado empurrando, a poça de fusão tem menor penetração e não interrompe o processo de solidificação no fundo do cordão, iniciado na reversão. Mas o seu calor reaquece esta região, promovendo o tratameno térmico.

\subsubsection{Efeito da inclinação da tocha}

Para confirmar se a inclinação da tocha fazia, de fato, diferença na técnica, foi escolhida a condição de $5 \mathrm{~mm}$ de reversão para ser produzida na condição puxando-empurrando. A Figura 15 apresenta a estrutura de solidificação obtida para esta solda. Por intermédio desta figura, é possível notar uma estrutura com grãos equixiais próximo à linha de fusão apenas quando a posição da tocha foi empurrando-puxando (avanço empurrando e reversão puxando). Quando a posição foi puxando-empurrando, observou-se uma estrutura totalmente colunar, desde a linha de fusão.

Esses resultados confirmaram a idéia de que a angulação da tocha tem influência sobre a estrutura de solidificação da solda na soldagem com a técnica switch back. Interessante observar, ainda, que para todas as soldagens sem o emprego da técnica, independentemente da inclinação da tocha, sempre foi obtida uma estrutura colunar, como pode ser verificado na Figura 16. Isto mostra um ponto positivo do emprego da técnica, desde que seja utilizada a inclinação adequada da tocha. 


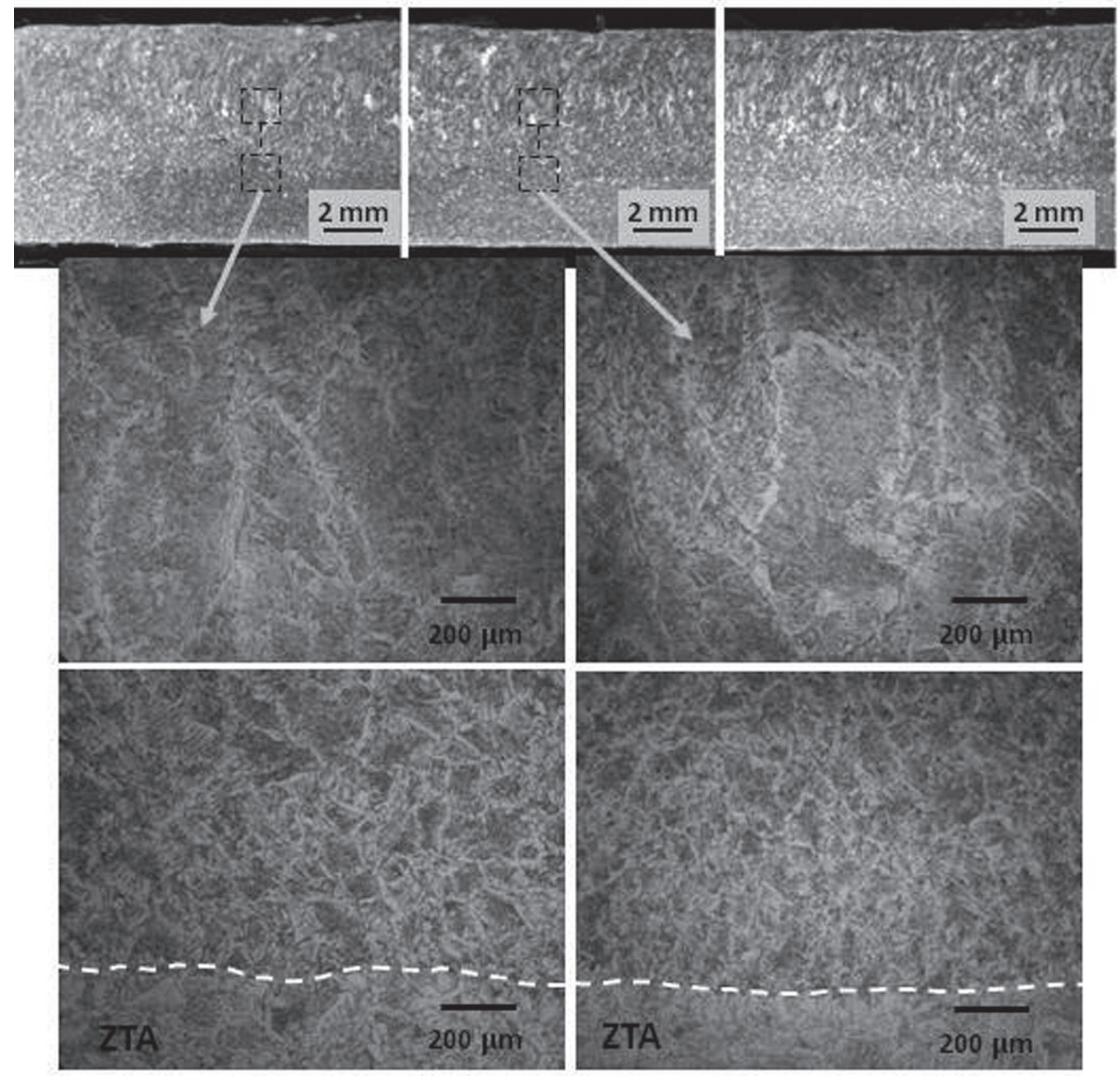

Figura 11 - Estrutura de solidificação do metal de solda com avanco de $10 \mathrm{~mm}$ e reversão de $5 \mathrm{~mm}$, percebendo-se grãos equiaxiais próximo à linha de fusão 


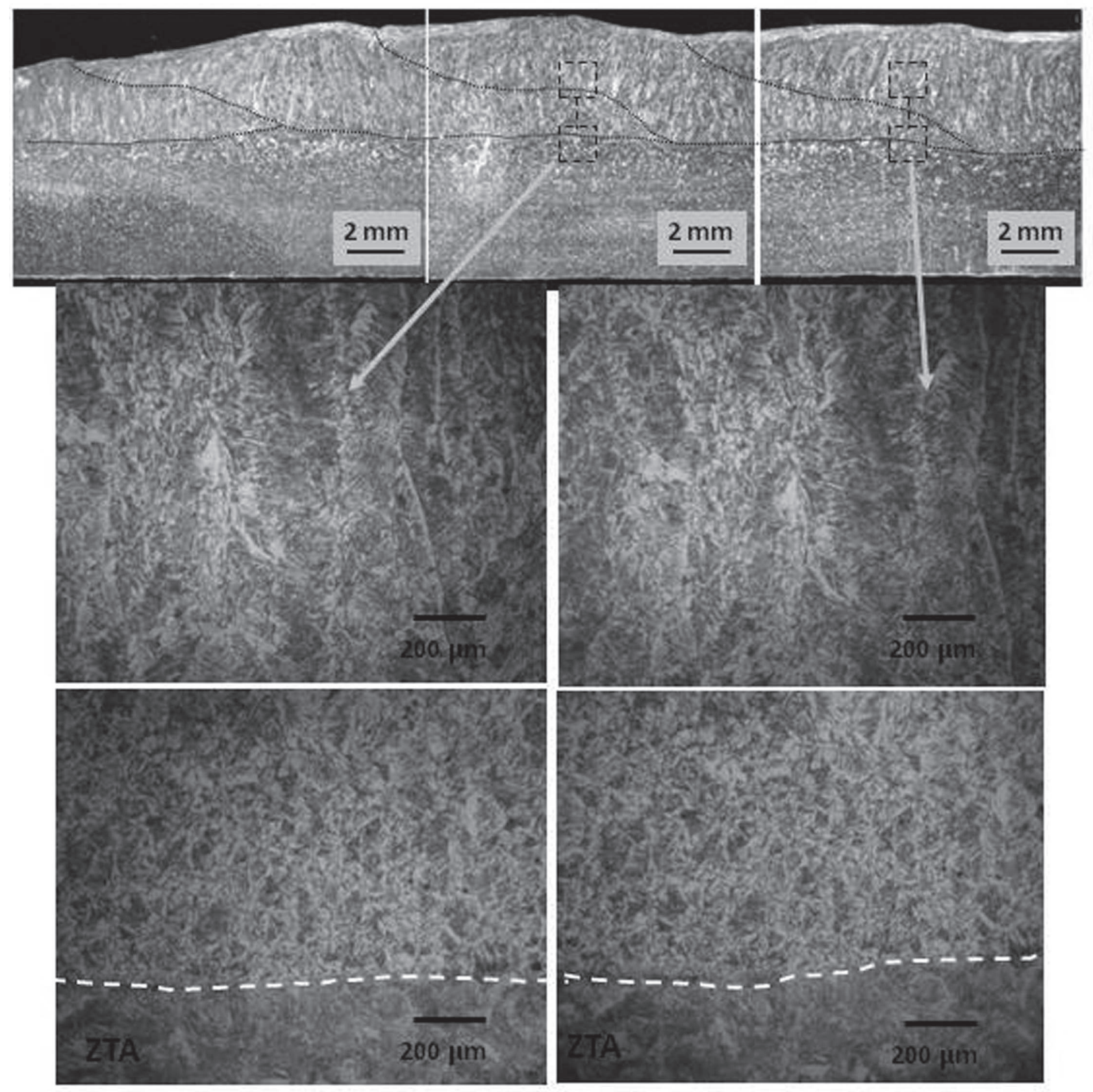

Figura 12 - Estrutura de solidificação do metal de solda com avanco de $30 \mathrm{~mm}$ e reversão de $20 \mathrm{~mm}$, percebendo-se grãos equiaxiais (mais finos que na figura 10) próximo à linha de fusão 


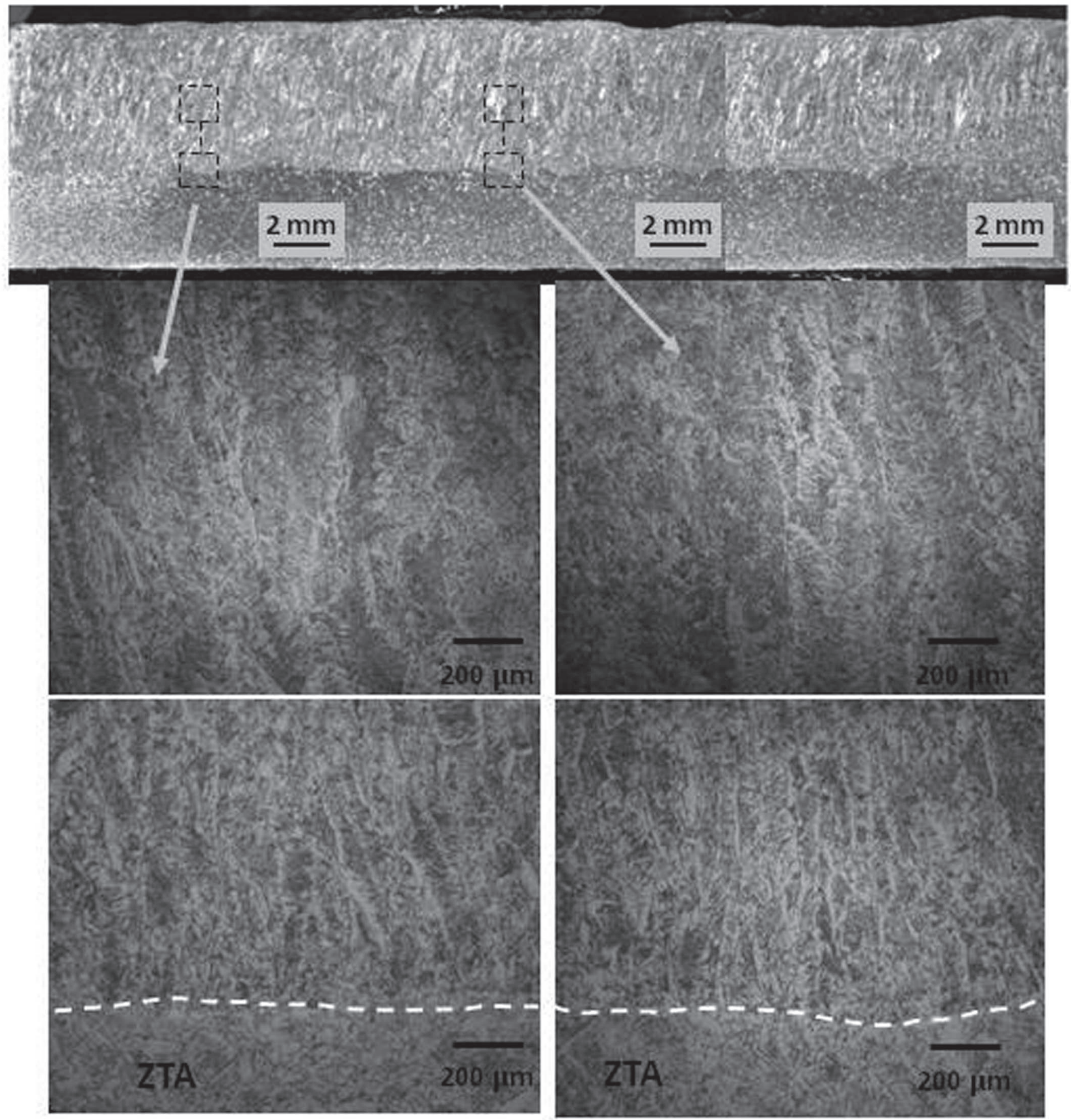

Figura 13 - Estrutura de solidificação do metal de solda sem o emprego da técnica, percebendo-se grãos colunares próximo à linha de fusão 

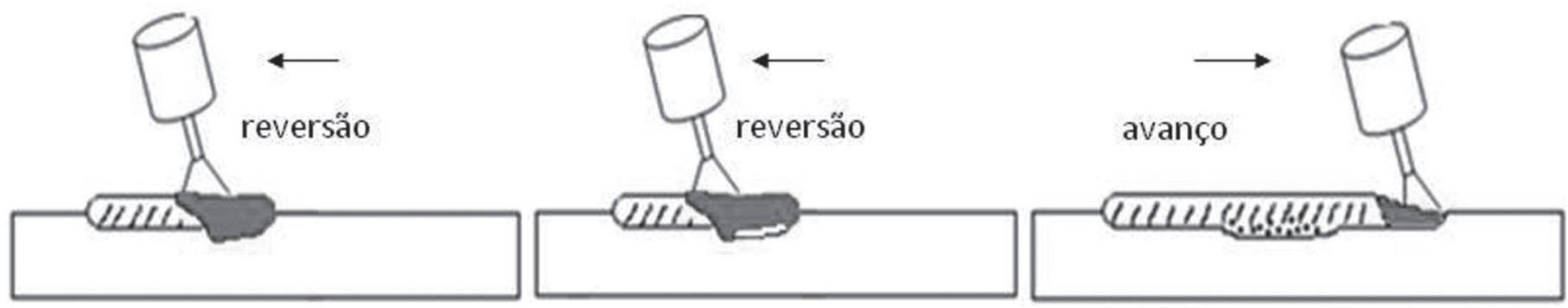

Figura 14 - Ilustração do efeito do ângulo da tocha sobre a estrutura de solidificação na soldagem Switch back com múltiplas reversões. Empurrando-puxando

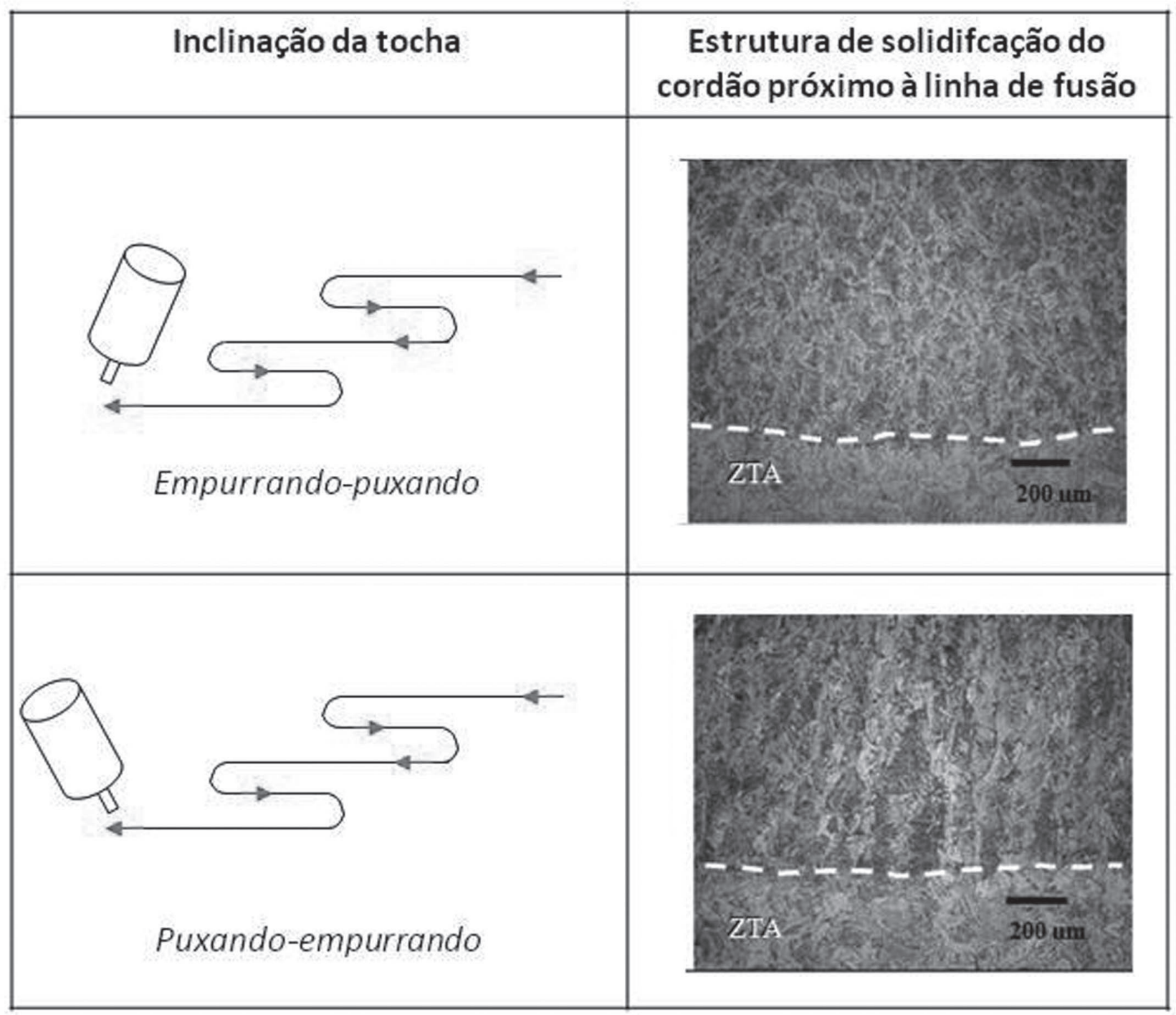

Figura 15 - Efeito da inclinação da tocha na soldagem switch back (comprimento de avanço de $10 \mathrm{~mm}$ e comprimento de reversão de $5 \mathrm{~mm})$ 


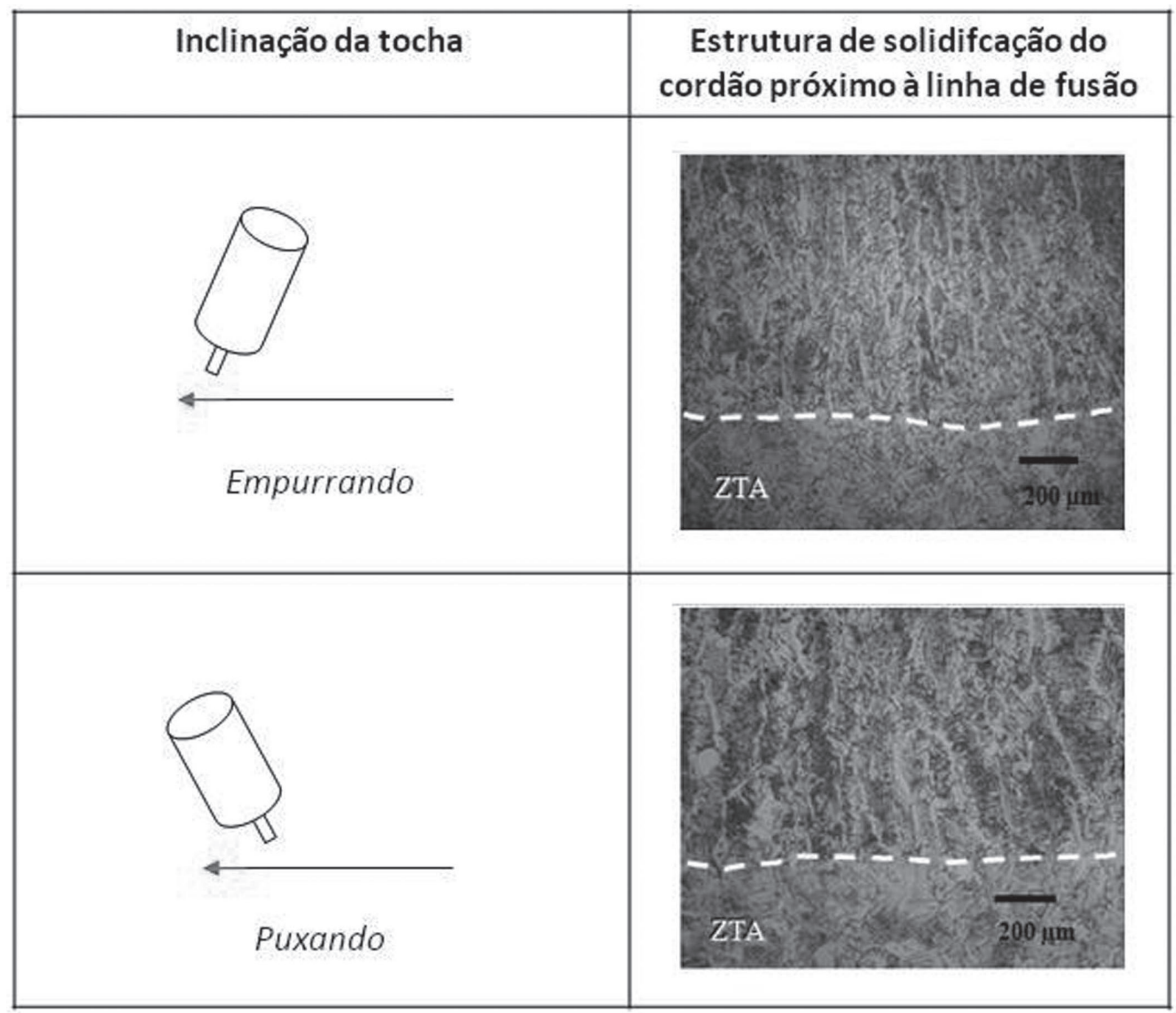

Figura 16 - Estrutura de solidificação do metal de solda produzido sem a técnica; estrutura predominantemente colunar desde a linha de fusão

\section{Conclusões}

Pode ser concluído com este trabalho que a reversão e a inclinação da tocha na soldagem MIG/MAG com a técnica switch-back afetam a estrutura de solidificação do cordão.

Para uma única reversão da tocha, a inclinação mais adequada seria a puxando-empurrando, para proporcionar uma estrutura de solidificação com grãos recristalizados do metal de solda, tal como ocorre na soldagem multipasses.

Para o caso das soldagens com múltiplas reversões, a inclinação mais adequada seria a empurrando-puxando, por possibilitar a formação de grãos equiaxiais próximos a linha de fusão. Nesta condição de soldagem switch back, é possível obter o refino destes grãos, desde que sejam empregados adequados comprimentos da reversão.

\section{Agradecimentos}

Os autores deste trabalho agradecem à CAPES (bolsa), CNPq (bolsa) e à FAPEMIG (infraestrutura) pelo apoio e incentivo a este trabalho.

\section{Referências Bibliográficas}

[1] BRUECKER, D., Increasing travel speed with pulsed MIG switch-back welding on lap joint, Relatório Interno LAPROSOLDA/UFU 15/2007, $16 \mathrm{p}$.

[2] KANEDO, Y; MAEKAWA, Y; YAMANE, S e OSHIMA, K. "Numerial Simulation of MIG Weld Pool in Switch Back Welding", IIW Doc 212-1106-07.

[3] YAMANE, Satochi; YOSHIDA, Testsuo e YAMAMOTO, Hikaru. "In Process Control of Weld Pool using Weaving Control in Switch Back Welding", IIW Doc XII-1949-08.

[4] YAMANE, Satochi et al; "Torch Weaving and Feed-Forward Control of Back Bead in One Side Backing less V Groove Welding by using Switch Back Welding”, IIW Doc XII-193107.

[5] KOU, Sindo. Welding metallurgy. 2a ed.. John Wiley \& Sons, 2003.

[6] SCOTTI e PONOMAREV, Soldagem MIG/MAG. Melhor entendimento, melhor desempenho, $1^{\mathrm{a}}$ edição, Artlíber Ed., SP, 2008, 284 p. 